improvement having been in substituting a later type of maize for the earlier ones grown by the Indians (Spragg Memorial Lectures on Plant Breeding. Eighth Annual Lecture: "Corn Breeding Experience and its probable eventual Effect on the Technique of Livestock Breeding". By Henry A. Wallace. Pp. 6. East Lansing, Mich. : Michigan State College). The application of the genetic methods of Shull and East, that is, inbreeding of strains followed by crossbreeding of particular types, has since greatly increased the yield. In 1938, probably at least fifteen million acres will be planted, yielding 100 million bushels more than if ordinary open-pollinated types were used. It is suggested that similar methods applied to animal breeding (that is, homozygosis followed by controlled heterosis), first to egg production in fowls, then to swine, sheep, dairy cows and finally to beef cattle can produce similar results, and the methods of swine breeding in Denmark are cited. Mr. Wallace concludes that in mankind compulsory sterilization and selection of types under a dictatorship will not bring about the desired eugenic improvement in the human race. A standardized preconception of the perfect man, after the Nazi ideal of an Aryan 'race', is a false eugenic idea which will lead, in the long run, to the failure of eugenic progress.

\section{Mexican Pictographic Manuscript}

A DOCUMENT of extreme interest to students of American pre-Columbian history and culture, the Mendoza Codex, now in the Bodleian Library, has been reproduced in facsimile by Mr. J. Cooper Clark, Captain T. A. Joyce providing a foreword. The Mendoza Codex is one of several pictographic manuscripts which have survived. It was prepared by the authority of Don Antonio de Mendoza, who was appointed the first viceroy of New Spain in 1535. The Codex - or rather collection of codices, for there are three-consists of seventy-one folio pages, the pictographs being in colour. The first part is a copy of an old Mexican chronicle, now lost, of the history year by year of the Lords of Tenochtitlan, now Mexico City, and a list of the towns they conquered. It covers from A.D. 1325 until the fall of the Empire in 1521. The second part is a carefully executed copy of the tribute roll to Motecuçuma, the Mexican ruler, by upwards of four hundred towns. The original from which this is copied is now in the National Museum of Mexico, and consists of fourteen folios painted on maguey leaves. The third part of the Mendoza Codex is a compilation by the scribe for Mendoza's use, recording the life of a Mexican from day to day from the cradle to the grave. Although some of the pictures were included by Lord Kingsborough in his book on Mexican art a hundred years ago, this valuable manuscript has never before been reproduced in accurate facsimile as a whole. It has now been printed for private publication by Messrs. Waterlow on hand-made Whatman paper, the pictographs being beautifully reproduced in colour. There are three volumes, of which the first contains Mr. Cooper Clark's translation of the Spanish text with commentary, the second the interpretation of the Nahuatl place-name glyphs, now for the first time rendered in English, and the third volume is the facsimile in colour of the manuscripts. The subscription price of the three volumes is twenty guineas.

\section{Very Low Temperatures}

Tre issue by the Science Museum of Books 2 and 3, describing the exhibits and outlining the lectures delivered at the special exhibition devoted to this subject in the Science Museum from March until June last year, completes the account of the exhibition. The three books have been edited by Mr. T. C. Craw. hall, with the assistance of Dr. O. Kantorowicz for Book 2. The first book, issued at $6 d$., gives a survey of physical principles and some applications; the second, issued at $2 s$., deals with the apparatus exhibited for temperature reduction, temperature and pressure measurement, liquefaction and solidification of gases, the properties of the products, their storage and their applications. Included in the methods of cooling is that of demagnetizing a paramagnetic material. The third book, issued at $1 s$. $3 d$., gives accounts of the development of low-temperature technique, by Prof. $M$. Travers, the industrial uses of low temperatures, by Messrs. C. G. Bainbridge, J. T. Randall and I. J. Faulkner respectively, and the approach to the absolute zero, by Dr. J. D. Cockroft, Prof. F. Lindeman and Prof. F. Simon respectively. The three books constitute a valuable record of the present position of a subject which promises to have many applications in industry.

\section{Crocodilian Energy}

IMPERIAL AIRWAys inform us that at the end of July, while one of their pilots was taking off in a flying boat at Port Bell on Lake Victoria, a crocodile gave a remarkable display of agility. The flying-boat had just taken to the air when, about forty yards away, a crocodile about nine feet long leapt full length out of the water, clearing the surface with its whole body by about four feet. Apart from its natural history interest, the occurrence was unusual, since, before a flying-boat takes off, the surrounding water is most carefully patrolled to guard against possible obstacles, and the flying-boats operate as far as possible from areas known to be haunted by crocodiles. This unusual air leap of the crocodile is analogous to the leaping of salmon and other fishes, for propulsion is due in both cases to the powerful movements of the tail muscles. The size of the individual, a young individual of a species Crocodilus niloticus, which may exceed twenty feet in length, illustrates a characteristic of many animals, that the young are notably more nimble than adults.

\section{Recent Minor Earthquakes}

AFTer the first series of shocks between July 5 and 9 (see NaTuRE of July 30, p. 203), in which buildings were badly cracked in Paliad and Botad though no lives were lost, further tremors have been recorded, and it was reported from Bombay on July 28 that all but the very poorest of inhabitants had deserted the town of Paliad. It is rare to find a

(Continued on p. 351) 
beneficial earthquake, but one such was reported from Cannes by The Times correspondent on July 29. An earthquake shock near the village of Réotier in the Hautes Alpes has removed an obstruction to the water supply which experts for many years have been trying to locate. The village fountain, dry for many generations, is now gushing forth water and the acute water shortage is at an end. On August 13, a small earth tremor was felt at Pwllheli in Wales, but no damage was done. It was probably due to subsidence in underground mine workings.

\section{Scientific Survey of the Cambridge District}

WHILE those who are visiting Cambridge for the first time-and indeed many who are re-visiting their Alma Mater-will have found the little "Concise Guide to the Town and University of Cambridge", originally written by John Willis Clark, of the utmost value and interest, an even wider audience will have welcomed the book "A Scientific Survey of the Cambridge District" specially prepared for the meeting by the local committee in Cambridge and edited by Dr. H. C. Darby. In fifteen chapters, the geology, physiography, climate, biology and history of Cambridge and the Fen District are summarized by specialists, with numerous references to the literature, and with appropriate maps and diagrams. In particular, there are, as would be expected, chapters on the drainage of the Fens and on the Breckland. The fact that this customary survey of the venue of the meeting is now sent out to members a week or so before the meeting opens gives the scientific worker time to learn in advance of the local topics and places likely to be of especial interest to him. The Survey is to be printed as usual in the Annual Report, and additional copies are also on sale (price 2s.).

\section{The Darwin Library at Down House}

THERE is at present a small collection of books, etc., known as the Darwin Library, at Down House, Downe, Kent, the home of Darwin from 1842 until 1882, which is now in the hands of the British Association. The major part of the existing collection consists of Darwin's own library, which belongs to the professor of botany in Cambridge for the time being, and was generously replaced in Down House by Sir Albert Seward during his tenure of that chair, an action confirmed by his successor, Prof. F. T. Brooks. For the rest, the number of Darwinian books in the possession of the Association is not large; whereas inquiries concerning such books are not infrequently made by visitors and others. The Down House Committee of the Association is endeavouring to collect $(a)$ all biographies of Darwin; (b) contemporary works on Darwinian theories and kindred subjects ; further (c) the collection of Darwin's own publications (books and papers) is not complete; and $(d)$ the Committee would gladly receive and preserve contemporary reviews of Darwin's works. Those who may be in a position to offer appropriate books or papers are asked, in the first instance, to communicate particulars thereof to the Secretary, British Association, Down House, Downe, Kent, in order that duplication may be avoided.

\section{German Trans-Atlantic Flight}

THE four-engined German monoplane Brandenburg landed at the Floyd Bennett Field, New York, at 15.54 (New York time) on August 11 after the first successful non-stop flight from Berlin. The time taken for the 3,942 miles' flight was a little more than twenty-five hours. The machine flew over Newfoundland and the Gulf of St. Lawrence, and at noon passed over St. John, New Brunswick. She encountered head-winds coming down the coast from Canada, and was flying at a height of $2,000 \mathrm{ft}$. at 155 miles an hour. The return flight was completed successfully on August 14 in just under twenty hours. The machine is said to have room for twenty-six passengers, and the flight was designed to show the feasibility of commercial non-stop travel between Germany and America. It is an all-metal monoplane with a wing-spread of $108 \mathrm{ft}$., it carries four 720-h.p. engines, and has a cruising speed of 196 m.p.h.

\section{International Geological Congress}

AT the seventeenth session of the International Geological Congress held in Moscow in 1937, the Geological Society of London extended an invitation, which was accepted, to hold the eighteenth session of the Congress in London in 1940. The first circular, which has just come to hand, contains preliminary details of the arrangements proposed. These include sessional meetings in London on July 31-August 8, 1940, and an attractive programme of excursionsalways an important and valuable feature of Congress activity-which will cover most of the important geology of Great Britain and Eire, and will afford the members of the Congress unrivalled opportunity of visiting many of the type-localities under expert guidance. A provisional list of fourteen subjects for discussion at the actual sessional meetings in London is given in the circular. Among these we may note magmatic differentiation, the geology of iron ore deposits, the geology of coal seams, the geology of petroleum, the distribution of early vertebrates, earth movements and evolution, the geological results of applied geophysics and the geology of sea and ocean floors. The organizing committee, mindful of the fact that this important Congress has not met in Great Britain since 1888, is anxious that the arrangements for the meeting in 1940 shall be as widely known and complete as possible. The office and headquarters of the Congress are at the Geological Survey and Museum, Exhibition Road, London, S.W.7, and all communications should be addressed to the general secretaries at that address.

\section{Agricultural Research Scholarships and Awards}

ON the recommendation of the Agricultural Research Council, the following awards of agricultural research scholarships, studentships for research in animal health and veterinary scholarships have been made by the Ministry of Agriculture and Fisheries and the Department of Agriculture for Scotland: Dr. R. E. Taylor (King's College, Newcastle-uponTyne) a three-year research scholarship in plant pathology, the first year to be spent at Cambridge; 